\title{
MATERIA
}

\author{
Ks. Jerzy Chmiel
}

\section{SZKICE HOMILII CHRZCIELNYCH (II)}

Czytania z Nowego Testamentu

163. Zostaliśmy razem z Chrystusem pogrzebani po to, abyśmy wkroczyli w nowe życie ( $\mathrm{Rz} 6,3-5)$.

Ten wyjątek z listu św. Pawła do Rzymian przypomina nam podstawowe fakty $z$ historii zbawienia: śmierć i zmartwychwstanie Chrystusa. Istnieje jakieśs podobieństwo między tymi faktami a życiem chrześcijanina. Podobieństwo to jest uwidocznione w obrzędzie samego chrztu.

1) Oto najpierw ,chrzest zanurzenia” i ,zanurzenie w śmierci”. Wydaje się może szokującym mówić już o śmierci przy nowo narodzonym życiu. Ale w ten sposób odbywa się wejście nowego życia w sferę działania, które kiedyś będzie musiało ustać na skutek śmierci. To jest realizm życia. Chrześcijaństwo patrzy realnie na życie i nie chowa głowy w piasek przed zjawiskiem śmierci.

Wyrażenie ,chrzest zanurzający” można zrozumieć lepiej, gdy przypomnimy sobie obrzęd chrztu dorosłych w pierwotnym chrześcijaństwie. Katechumeni wchodzili do wody znajdującej się w sadzawce chrzcielnej. Możemy takie osokne baptysteria oglądać dzisiaj w Rzymie, np. historyczne baptysterium przy bazylice św. Jana na Lateranie. Dzisiaj główkę dziecka polewa się delikatnie wodą chrzcielną, a chociaż nie ma dzisiaj obrzędu zanurzenia, to pozostaje sens tego wyrażenia.

„Zanurzyć się" to znaczy zejść niżej, schować się pod powierzchnię, niejako zostać pogrzebanym - ruch zstępowania to ruch śmierci. Chrzest jest znakiem pogrzebania grzechu, ale nie jest to tylko jakieś indywidualne oczyszczanie się (na konto własne). Dzieje się to na mocy śmierci Jezusa Chrystusa, który umarł za nasze grzechy. Gdyby nie było zbawczej śmierci Jezusa Chrystusa, nasz znak chrztu-zanurzenia byłby tylko tęsknym wołaniem człowieka o oczyszczenie, tak jak się to działo w misteriach pogańskich (np. w kulcie Mitry). Chrzest jest więc zanurzeniem w śmierć Chrystusa - oddajemy to dziecię Chrystusowi za nas cierpiącemu i umarłemu. Ale nie oddajemy go na śmierć. Oddajemy je na życie. 
2. Bo Chrystus zmartwychwstał $A$ jeśliby Chrystus nie zmartwychwstat, daremne jest nasze nauczanie, próżna jest także wasza wiara - nauczal św. Paweł (1 Kor 15, 14). Gdyby Chrystus nie powstał z martwych, obrzęd chrztu, jakiego teraz dokonujemy, nie miałby sensu, skuteczności - pozostałby znakiem zewnętrznym. A tak dzięki zmartwychwstaniu Chrystusa - dziecko wewnętrznie wkracza w nowe życie. Oddajemy to dziecię Chrystusowi zmartwychwstałemu. Mamy tutaj symbole Zmartwychwstania: zapalony paschał, wode chrzcielną z wielkanocnej soboty.

3. To oddanie Chrystusowi zmartwychwstałemu jest na zawsze. Bo przecież po najdłuższym życiu przyjdzie śmierć. Ale dla tego dziecięcia nie będzie ona straszna, gdyż nie będzie końcem jego życia. Nowo ochrzczone dziecko będzie zjednoczone z Chrystusem, będzie miało ,pieczęć" Jezusa na swojej duszy, to, co nazywamy niezatartym znamieniem chrztu - będzie to znak rozpoznawczy, że należy do Chrystusa. Dlatego będzie uzdolnione do dalszego życia, którego śmierć nie zniszczy.

Kiedyś nasze ciała zmartwychwstaną i doznają przemiany. Tak nas uczy wiara, choć nie umiemy teraz wyobrazić sobie, jak to będzie wyglądać. Sztuka próbuje przybliżyć nam te chwile, toteż pełni zadumy stajemy przed obrazami sądu ostatecznego. We Mszy św. modląc się za zmarłych tak argumentujemy: „Pamiętaj o słudze Twoim (albo służebnicy Twojej), którego z tego świata wezwałeś do siebie. Spraw, ażeby ten, który przez chrzest został włączony w śmierć Twojego Syna, miał również udział w Jego zmartwychwstaniu, gdy wskrzesi ciała zmarłych $\mathrm{z}$ prochu ziemi i upodobni nasze ciała podległe zniszczeniu do swojego ciała uwielbionego", (z III modl. eucharyst.) A więc chrzest jest tytułem do naszej przyszłej chwały, która nie ulęknie się śmierci i jej zniszczenia.

$\mathrm{O}$, błogosławiony to dar, który składacie temu nowo narodzonemu dziecku. To dar życia wiecznego, dar, który potem będzie musiał być wypracowany osobiście, gdy to dziecię dorośnie, ale to dar, za który powinno być wam potem wdzięczne.

A my łączymy się wspólnie w tym obrzędzie chrzcielnym w wyznawaniu Boga. Tak pisał św. Hilary biskup, w IV wieku: „Trzeba więc wierzyć w Boga, którego mocą Chrystus został wskrzeszony; z Chrystusem głosi nasza wiara i nasze zmartwychwstanie" (PL 10, 288).

164. Bóg nas powotat, abyśmy byli podobni do obrazu Jego Syna (Rz 8, 28-32). łani?

1) Zastanówmy się, co to znaczy, że jesteśmy przez Boga powo- 
a) Jesteśmy najpierw powołani do bytu. Tak rzadko zdaje.ny sobie sprawę z tego, jakim darem jest to, że żyjemy. Człowiek roże doświadczyć wielu rzeczy, przejść wiele cierpień, ale najważniejsze jest to, że jeszcze żyje.

b) Jesteśmy dalej powołani przez Boga do uczestnictwa w Jego życiu przez wiare $w$ Jezusa Chrystusa. To jest wielki dar, chociaż wydawać się nam może wynikiem układu stosunków zewnętrznych (,przypadkowo znalazłem się w statystyce chrześcijan"). Św. Paweł używa wielu określeń, takich jak: „Bóg współdziała”, „od wieków poznał", ,przeznaczył”, ,powołał”, ,,usprawiedliwił”, „obdarzył chwałą", ażeby wykazać, że nasze powołanie do wiary leżało w planach Boga czuwającego nad ludzkością.

c) A były to plany Wielkiej Miłości, bo Bóg jest Miłością (1 J 4, 8. 16). Sw. Paweł zapewnia nas, że Bóg z tymi, którzy Go miłuja, współdziała we wszystkim dla ich dobra. Jesteśmy powołani przez Bożą Miłość, abyśmy miłowali wszystkich.

Oto rodzice przynieśli dziecko, aby dokonać obrzędu chrztu. Dziecko - owoc miłości. Pochyla się nad nim cała społeczność wierzących, aby dopełnić tego obrzędu. Sam Bóg, który powołał wszystko, będzie tutaj tym, który da i łaskę, i wzrost. Aby owoc miłości dojrzewał do miłości. Rodzice, krewni, przyjaciele będą się zastanawiać, kimże będzie to dziecie, podobnie jak zastanawiali się nad Janem Chrzcicie.lem w kolebce (por. Łk 1, 66). Kochające serca będą snuć wizje pięknej przyszłości. Tylko miłość potrafi tak pragnąć i życzyć. I tak jak to dziecko jest w centrum pełnej wizji miłości swoich najbliższych, tak jest też w planach kochającego Boga, z którym się zespoli w jedno życie, aby tam, gdzie Bóg jest, było i ono.

To jest istota powołania do wiary, które dokonuje. się teraz w ezasie chrztu.

2) Ochrzczony jest podobny do obrazu Syna Bożego.

Dziecko jest obrazem miłości swoich rodziców. Dziecko przedłuża miłość, utrwala ją, zachowuje ją zawsze młodą. Jaka to radość rodziców - móc rozpoznać w dziecku swoją miłość! Dziecko jest obrazem swoich rodziców pod względem duchowocielesnym. Dziedziczy dobre i - niestety - złe cechy. Jest często podobne nawet fizycznie do swoich rodziców.

Ten obraz można przenieść na sferę stosunku duchowego do Boga. Nowo ochrzczone dziecko jest obrazem Bożym, bo ma łaskę Bożą, która odbija się w nim niejako. Zachowało się opowiadanie, że ojciec Orygenesa klękał u kołyski swego synka i całował pierś jego - bo w sercu dziecka wyciśnięty był obraz Boga.

Módlmy się, aby ten obraz Boży odbity w duszy nowo ochrzczo- 
nego dziecka nie zacierał się nigdy, ale coraz to bardziej przeglądał ku dojrzałej świadomości dziecka Bożego.

165. W jednym Duchu zostaliśmy ochrzczeni, aby stanowić jedno ciało (1 Kor 12, 12-13).

Z różnych stron naszej parafii przyniesiono dzieci do chrztu. Zgromadzili się tutaj ludzie początkowo sobie nawzajem nie znani, aby teraz poczuć się wspólnotą. Oto znak jedności Ciała Mistycznego Chrystusa. Chrzest jednoczy w Chrystusie. Każdy pozostaje sobą, nikt nie traci swej odrębności, ale wszyscy czujemy się zjednoczeni.

Zadaniem chrześcijaństwa jest jednoczyć. Za dużo istnieje różnic pomiędzy ludźmi. A jednak trzeba, ażeby odczuli wzajemną jedność. Chrzest, który obecnie sprawujemy, jest takim czynnikiem jednoczenia. Pomyślcie: te dzieci są poprzez wspólny obrzęd chrztu związane więzami wspólnoty. A wspólnota ta jest oparta nie tylko na naszym społecznym odczuciu, które zresztą może ulec zmianie, lecz na Jezusie Chrystusie, który nas wszystkich wewnętrznie łączy. Pomiędzy nami a tym dziećmi wytwarzają się duchowe więzy wszystkie one prowadzą do Chrystusa. Cała społeczność chrześcijańska świadczy o włączeniu tychże dzieci do Ciała Mistycznego Chrystusa.

Poprzez obrzędy chrztu ,,staje się widoczne, że wiara, w której chrzci się dzieci, jest skarbem nie tylko jednej rodziny, lecz całego Chrystusowego Kościoła" (Chrzest dzieci, n. 4). Szczególne obowiązki spadają na rodziców dziecka i na chrzestnych. Rodzice dziecka mają chrześcijański obowiązek doprowadzić dziecko do poznania Boga i do wejścia w pełne, świadome chrześcijaństwo - mają więc za zadanie dbać o prawidłowy wzrost dziecka w Ciele Chrystusowym. Winni w tym im pomagać rodzice chrzestni i cała społeczność parafialna.

Tym, który powoduje wzrost w Ciele Chrystusa, jest Duch Swięty. Sw. Paweł pisał o pieczęci Ducha Swiętego (zob. 2 Kor 1, 22; Ef 1, 13), a św. Ambroży tak pouczał nowo ochrzczonych dorosłych: „Otrzymałeś pieczęć Ducha, mądrości i rozumu, ducha rady i męstwa, dúcha wiedzy, pobożności i bojaźni Bożej. Zachowaj to, co otrzymałeś! Tę pieczęć wycisnął w Tobie Bóg Ojciec, umocnił cię Chrystus Pan i zostawił w twoim sercu zadatek Ducha" (PL 16, 419).

Dzieci, które dzisiaj chrzcimy, nie mogą jeszcze rozumieć naszych pouczeń. Muszą do tego dorosnąć. Obowiązkiem waszym, rodzice, będzie pouczać je o zadaniach chrześcijanina wynikających z przyjętego chrztu, troszczyć się o ich należyte wykształcenie religijne i wychowanie moralne. Oby te dzieci wzrastały w atmosferze łączności i więzi społecznych, które płyną nie tylko z krwi i ciała, ale od Boga, naszego wspólnego Ojca. 
166. Wszyscy, którzy zostaliście ochrzczeni, przyoblekliście się w Chrystusa (Ga 3, 26-28).

W pierwszych wiekach chrześcijaństwa nowo ochrzczeni dorośli otrzymywali na znak łaski chrztu białe odzienie, w którym chodzili tydzień po Wielkanocy (stąd nazwa Niedzieli Białej). Obecnie śladem tego jest nakładanie pod koniec obrzędów białej szatki na każde dziecko. Jest to tylko symbol, ale jakże wymowny.

,Przyoblec się w Chrystusa" oznacza przejście na całkowitą służbe Chrystusa. To piękne wyrażenie św. Pawła moglibyśmy dzisiaj przetłumaczyć: „,przywdziać mundur Chrystusa” lub „,nosić odznakę Chrystusa”. Ale „przyoblec Chrystusa” oznacza jeszcze coś więcej - upodobnić się całkowicie do Chrystusa. A to oznacza słowo „chrześcijanin" - Chrystusowy, wierzący w Chrystusa. I to również oznacza słowo ,chrzest" - stać się Chrystusowym, należeć do Niego.

Jakże ogromnie cenne jest to ,przyobleczenie w Chrystusa" dia wychowania człowieka. To znosi podziały społeczne, niweluje różnice posiadania, wykształcenia, rasy, pochodzenia. Człowiek bardzo jest narażony na pokusy wyróżniania się. Między innymi i przez strój. Jakże niestety często dzieci są zabawkami w ręku rodziców chcących na ich ubrankach podkreślić swój stan majątkowy. „Przyobleczeni w Chrystusa" zwracają przede wszystkim uwagę na wartości duchowe i na wzajemną miłość. Tak bardzo nam trzeba podkreślenia wartości ducha, tak nam bardzo grozi to zagubienie się w rozmaitych ubraniach.

Oby te dzieci zachowały owo ,przyobleczenie w Chrystusa" na całe swoje życie chrześcijańskie: do pierwszej Komunii św., do innych sakramentów, do śmierci. Oby im Chrystus towarzyszył wszędzie i zawsze! 